THE AUTOBIOGRAPHY OF

Benjamin Franklin 
Sponsored by

The American Philosophical Society

and Yale University 
THE AUTOBIOGRAPHY OF

\title{
Benjamin Franklin
}

SECOND EDITION

\author{
EDITED BY LEONARD W. LABAREE, \\ RALPH L. KETCHAM, HELEN C. BOATFIELD, \\ AND HELENE H. FINEMAN
}

WITH A NEW FOREWORD

BY EDMUND S. MORGAN

\author{
$\mathrm{NB}$ \\ Yale Nota Bene \\ YALE UNIVERSITY PRESS \\ New Haven \& London
}


First published as a Yale Nota Bene book in 2003.

First published by Yale University Press in 2964.

Copyright (C) 2964 by Yale University. All rights reserved.

This book may not be reproduced, in whole or in part, in any form (beyond that copying permitted by Sections 107 and 108 of the U.S. Copyright Law and except by reviewers for the public press), without written permission from the publishers.

For information about this and other Yale University Press publications, please contact:

U.S.office sales.press@yale.edu Europe office sales@yaleup.co.uk

Printed in the United States of America.

Library of Congress Control Number: 2002224383

ISBN 0-300-09858-8 (pbk.)

A catalogue record for this book

is available from the British Library.

109876543 